\title{
The Effectiveness of Using Task-Based Instruction in Enhancing Vocational Students' Communicative Performance
}

\author{
Mohammed Ibrahim Mohammed Abdullah, Khaled Soliman Mahdi Soliman \\ Department of English Language Teaching, ITQAN College, Ras Tanura, KSA \\ Email: mahmmed_abdullah@yahoo.com
}

How to cite this paper: Abdullah, M. I. M., \& Soliman, K. S. M. (2019). The Effectiveness of Using Task-Based Instruction in Enhancing Vocational Students' Communicative Performance. Open Journal of Modern Linguistics, 9, 446-468.

https://doi.org/10.4236/ojml.2019.96035

Received: September 18, 2019

Accepted: November 24, 2019

Published: November 27, 2019

Copyright $\odot 2019$ by author(s) and Scientific Research Publishing Inc. This work is licensed under the Creative Commons Attribution International License (CC BY 4.0).

http://creativecommons.org/licenses/by/4.0/

\begin{abstract}
The study aimed at investigating the effect of the task-based instruction in enhancing industrial students EFL proficiency and communicative skills, first year, Miet Ghamer Industrial School Egypt. It also tests whether using the task-based instruction motivates industrial students to learn English in real situations and also test whether using the task-based instruction improves the industrial students EFL proficiency and communicative skills. The research sample is included one experimental group and one control group, the experimental group consisted of (40) students and the control group of (40) students, too. Tools of the research included a pre-post English language proficiency test, a pre-post communicative skills test, a student manual and finally a teacher guide. Results of the research showed that the effect size of the task-based instruction was great in developing the industrial students' EFL proficiency and communicative skills. The research has come to an important recommendation which is more programs and courses should be developed according to the task-based approach for developing both proficiency and communicative skills of Students of English for specific purposes and ESP classrooms.
\end{abstract}

\section{Keywords}

ESP (English for Specific Purposes), Task-Based Instruction, Task-Based Syllabuses, EOP (English for Occupational Purpose), Language Proficiency

\section{Introduction}

\subsection{Background}

With the increasing number of business and industry jobs that require a high 
level of proficiency in English, ESP has established itself as an inevitable movement in the field of TEFL. English for specific purposes (ESP) is the English instruction which is based on actual and immediate needs of learners who should successfully perform real life tasks (Smoak, 1994). Dudley \& ST. John (1998) suggested that ESP is designed to meet specified need of the learner. Stape (2002) concluded that the role of needs analysis in an ESP setting is crucial as the focus is very much on the learners and the language and the linguistic skills, as ESP pedagogy is driven by learner centeredness, (Lixin, 2004).

Jais (2002) proved that needs analysis should be concerned with the establishment of communicative needs resulting from an analysis of the communication in the target situation. And so, we must be ready to develop a course that teaches authentic language from many different fields based on accurate needs analysis and appropriate materials (Smoak, 2003). ESP is an approach to language teaching in which all decisions as the content and the method are based on the learner's reason for learning ( $\mathrm{Li}, 2004)$.

Robinson (1991: p. 5) states: "What we are really involved in as ESP practitioners is not so much teaching English for specific purposes but teaching English to specific people."

Thus, learners themselves are the center of the teaching-learning process in ESP classes. Widdowson (1987: p. 102) states: "it becomes feasible in principle to design programs of English for academic study to accord with the learners' cognitive bias because the learners have already grouped themselves by the process of a kind of natural selection in their choice of subject specialization."

An ESP course is directly concerned with the purpose for which learners need the English language. They require English as a mean of furthering their specialist education or as a means of performing their role as scientists and technologists efficiently, (Amany, 1997) ESP highlights a sophisticated approach to the needs of students in the field of language skills that are directly related to their work.

ESP branches off early into (EOP). According to Anthony (1997) (EOP) "English for occupational purposes" can be defined as the portion of the curriculum which prepares students for gainful employment in occupations ranging from low-skilled to sophisticated jobs in technical fields. The purpose of (EOP) courses is to fulfill the needs of students in preparing themselves for the work place, and then the needs of students which will be experienced through communication in the target language outside classrooms (Stape, 2002).

Teaching languages for particular purposes rather than for general mastery is an idea born of the fact our students do not have the patience or the motivation to attend English lessons unless the syllabus is based on the daily communicative situations which they may face in their careers. Thus, improving the learners' communicative competency in the target situation is always the ultimate goal of any ESP instruction. This, consequently, implies increasing the learners' efficiency in the occupational filed related to the instruction.

The growth of ESP can be traced back to the early 1960's, English for Specific 
Purposes (ESP) has grown to become one of the most prominent areas of EFL teaching today. Its development is reflected in the increasing number of universities offering an MA in ESP (e.g. The University of Birmingham, and Aston University in the UK) and in the number of ESP courses offered for overseas students in English speaking countries. There is now a well-established international journal dedicated to ESP discussion, "English for Specific Purposes: An international journal", and the ESP SIG groups of the IATEFL and TESOL are active at their national conferences.

In Egypt too, the ESP movement has shown a slow but definite growth over the past few years. In particular, increased interest has been spurred by the Ministry of Education's to improve the ESP syllabuses in the technical schools (commercial, industrial, agriculture, nursing and physical education). This has led to a rapid growth in English courses aimed at specific disciplines, e.g. "English for Chemists", in place of the more traditional "General English" courses.

The ESP classroom comprises unique situations derived from the learners' real experiences and makes use of their eager desire to express themselves. Hilary and Scott (1984) describe the ESP classroom as follows:

"The ESP classroom is seen as a learning environment valid in its own right, authentic to itself, and able to draw upon the accumulated stock of TEFL experience and know-how." In ESP, the content of the course seems to be the most outstanding feature that distinguishes an ESP course from that one written for general purposes. Thus, in ESP the content of the course is always a reflection of the target language behavior which is related to the learners' specialized subject.

\subsection{ESP Has the Following Characteristics}

1) ESP is defined to meet specific needs of the learners.

2) ESP makes use of underlying methodology and activities of the discipline it serves.

3) ESP is centered on the language appropriate to these activities in terms of grammar, lexis, register, study skills, discourse and genre.

4) ESP may be related to or designed for specific disciplines.

5) ESP may use, in specific teaching situations, a different methodology from that of General English.

6) ESP is likely to be designed for adult learners, either at a tertiary level institution or in a professional work situation. It could, however, be for learners at secondary school level.

7) ESP is generally designed for intermediate or advanced students.

8) Most ESP courses assume some basic knowledge of the language systems.

\subsection{There Are Certain Aspects Seem to Be Essential Traits of ESP Courses}

1) ESP courses depend on the selection of materials that are related to the students' needs. 
2) The ESP course should have a purpose and this purpose can be expressed and tested.

3) The student of ESP is an adult with previous backgrounds of English.

4) In most cases, the ESP course lasts for a limited period of time.

English for Specific Purposes (ESP) is known as a learner-centered approach to teaching English as a foreign or second language. It meets the needs of (mostly) adult learners who need to learn a foreign language for use in their specific fields, such as science, technology, medicine, leisure, and academic learning. This course is recommended for graduate students and foreign and second language professionals who wish to learn how to design ESP courses and programs in an area of specialization such as English for business, for Civil Engineering, for Academic Purposes, and for health service purposes. In addition, they are introduced to ESP instructional strategies, materials adaptation and development, and evaluation.

\subsection{ESP Objectives Include}

1) To develop an understanding about the factors that led to the emergence of ESP and the forces, both theoretical and applied, that have shaped its subsequent development.

2) To assist students develop needs assessments and genre analyses for specific groups of learners.

3) To provide guidelines to adapt or create authentic ESP materials in a chosen professional or occupational area and to critically evaluate currently available materials, including technology-based ones.

4) To become knowledgeable about assessment procedures appropriate for ESP and apply this knowledge in developing course and lesson evaluation plans in their professional or occupational area.

5) To assist students in preparing a syllabus, lesson and assessment plan based upon their needs assessments and genre analyses.

The definition Dudley-Evans (1984) offers is clearly influenced by that of Strevens (1988), although he has improved it substantially by removing the absolute characteristic that ESP is "in contrast with 'General English" (Johns \& Dudley Evans, 1991: p. 298), and has revised and increased the number of variable characteristics. The division of ESP into absolute and variable characteristics, in particular, is very helpful in resolving arguments about what is and is not ESP. From the definition, we can see that ESP can but is not necessarily concerned with a specific discipline, nor does it have to be aimed at a certain age group or ability range. ESP should be seen simple as an "approach" to teaching, or what Dudley-Evans (1984) describes as an "attitude of mind". Such a view echoes that of Hutchinson et al. (1987:19) who state, "ESP is an approach to language teaching in which all decisions as to content and method are based on the learner's reason for learning".

Task-based instruction is a type of integrated skills approach, as contrasted to 
the purely segregated approach, which exposes English language learner to authentic language and challenges them to interact naturally in the language (Oxford, 2001). Task based instruction is frequently promoted as an effective teaching approach, superior to traditional method, which is often justified by the claim that linguistic regularities are acquired through noticing through communicative activities (Swan, 2005).

If we agree with the above introduction, we begin to see how broad ESP really is. In fact, one may ask "What is the difference between the ESP and 'General English' approach?" Hutchinson et al. (1987: 53) answer this quite simply, "in theory nothing, in practice a great deal". In 1987, of course, the last statement was quite true. At the time, teachers of "General English" courses, while acknowledging that students had a specific purpose for studying English, would rarely conduct a needs analysis to find out what was necessary to actually achieve it. Teachers nowadays, however, are much more aware of the importance of needs analysis, and published textbooks have improved dramatically allowing the teacher to select materials which closely match the goals of the learner. Perhaps this demonstrates the influence that the ESP approach has had on English teaching in general. Nevertheless, the line between where "General English" courses stop and ESP courses start has become very vague indeed.

Communicative Task-Based Language Teaching (CTBLT) is a form of Communicative Language Teaching in which tasks or activities are viewed as central to meaningful language learning (Nunan, 1989, 2004; Skehan, 1998). The primary goal of Communicative Task-Based Language Teaching is to prepare learners with language that matches their needs (Long, 1985; Long \& Crookes, 1993) and is suited to their context and familiarity (Ellis, 2003). Teaching and learning activities under Communicative Task-Based Language Teaching typically involve learners as problem solvers who have to fulfill a specified real world task in relation to the instructional objectives or learning outcomes such as making travel arrangements with a travel agent (Crookes, 1986; Prabhu, 1987).

To investigate the present situation of the communicative skills, the researcher conducted two pilot studies. The aim of the first study was to measure the students' communicative skills and their ability to negotiate meaning during a task. The sample of this study consisted of (40) students in the first of vocational school, Miet Ghamer city, Egypt. Those students were from different levels and their scores showed inability to communicate effectively inside or outside the classroom.

The aim of the second pilot study was to measure the students' proficiency level of English and the result of this test showed shortcoming in the communicative abilities of the students, (listening, speaking, reading, writing). The sample of this study was of (40) students in the first year of the vocational school, Miet Ghamer city, Egypt. The scores of this group was very low, what showed low proficiency level of English.

Showing weakness in the communicative skills and the EFL proficiency of the 
vocational schools and the ESP training projects during my work in an international academy in Saudi Arabia urged the researcher to tackle the problem of the present study.

\subsection{Description of the Present English Course for First Year Vocational Schools}

(One book for all majors including Mechanics which is our concern in this study)

The present English course is entitled "English for Industrial Schools" published by "Egyptian International Publishing Company-Longman, 2000" and it is updated version for ministry of Education, Egypt. The books consists of the following:

1) A student's book which presents 12 revised units for class activities along with 6 revision units distributed throughout the book.

2) A workbook which gives additional practice to the language of the units as well as developing writing skills. It includes a further six revision units and two practice tests.

3) A resource book which allows students to look up words in English and see their meanings in Arabic, thus developing their dictionary skills.

4) A teacher's guide which gives detailed, step by step lesson notes, background information for teachers and suggestions for follow up work.

5) A cassette tape containing pronunciation models and the listening texts which accompany the Student's book.

6) A website (www.longmansec.com.eg) which provides support material.

\subsection{A Description of the Situation of Teaching English in Industrial Schools in Egypt in 2013}

The researcher has surveyed the current book of the first year in the industrial schools and came up with many important notices:

1) The English course lacks the components of effective ESP.

2) The English course presents pure industrial information.

3) The English course is taught to all majors, the thing that makes no difference between the eight majors of the first year.

4) The textbook does not focus on one specific section of the school.

5) The exercises do not support group work or problem solving techniques.

6) Fluency exercises are very limited.

7) Listening exercises are not presented well.

\subsection{The Researcher Has Interviewed Teachers and Students of the Industrial Schools and the Interview Showed the Following}

1) The majority of the English language teachers are not satisfied with the current book as they consider it inadequate and unsuitable for all the sections inside the school. 
2) The majority of the students expressed their dissatisfaction about the book as it doesn't meet their needs. Students feel that what they learn inside English class has no relation to the real life, especially those in the mechanics section.

3) Industrial students feel that they lack information about their section and they can't express that in English.

4) The researcher noticed very poor motivation for learning ESP.

5) Teacher of ESP are complaining about lack of facilities in many schools, sometimes there is no cassette to run the listening exercises.

6) Industrial students expressed their wish to study ESP in their specific specialization not a course for all the sections as well as their wish to be able to communicate successfully in the target language which helps their careers.

\subsection{Statement of the Problem}

The problem of the present study is that students at Miet Ghamer Vocational School are weak in the level of proficiency as well as the communication skills, so the researcher is attempting to test the effectiveness of the proposed taskbased instruction for enhancing industrial students EFL proficiency and communicative skills. Thus, this research is attempting to answer the following question:

What is the effectiveness of the task-based instruction in enhancing EFL proficiency and communicative skills of Industrial students?

This question can be divided into the following sub-question:

1) What are the EFL proficiency communicative skills needed for industrial students?

2) What are the characteristics of the task-based approach that can be designed for industrial students?

3) How far do the communicative skills affect the EFL proficiency skills?

4) What is the effectiveness of using the task-based approach in enhancing the EFL proficiency levels?

5) What is the effectiveness of using the task-based approach in enhancing the communicative skills?

\subsection{Objectives of the Study}

The primary objectives of this study is to improve teaching English in the industrial schools, there are also some other objectives, for example:

1) To improve the students' linguistic skills (listening, speaking, reading, writing), particularly speaking.

2) To explain how to apply effectively task-based approach for teaching ESP.

3) To widen teachers' knowledge and improve their performance in teaching ESP.

4) Preparing first year industrial students to be able to speak fluently.

5) Preparing first year industrial students to use their ESP language for real life situations, particularly their work field. 
6) Motivating first industrial students to be creative, initiative and confident.

7) Investigating the practical techniques of the task-based approach and how they can develop the students' EFL proficiency and communicative skills.

8) Developing the ability to apply the techniques of the task-based instruction in different situations, schools and majors of ESP.

9) Enhancing the students' understanding of the basic grammatical structure of English and increase their ability to use them accurately.

10) Developing the ability to Listen, understand and respond to industrial information.

11) Developing the ability to read, understand and write industrial texts accurately.

12) Having solid information about industrial English.

\subsection{Hypotheses of the Research}

1) Using task-based approach in first year industrial schools can increase students' level of English language proficiency.

2) There will be a positive correlation between applying the task-based approach and the communicative skills.

3) There will be a positive correlation between applying the task based approach and the accuracy of the writing skill.

4) There will be statistically significant difference between the mean scores of the experimental group students in the pre and posttest of English language proficiency in favor of the post-test.

5) There will be statistically significant differences between the mean scores of the experimental group students in the pre and posttests of the communicative skills in favor of the post test.

6) There will be statistically significant differences between the mean scores of the experimental and the control groups in the post-test of English language proficiency in favor of the experimental group.

\subsection{Limitation of the Study}

This research is limited to industrial schools, first year students, majored in mechanics, Miet Ghamer Vocational School, Mansoura, Egypt. The researcher has chosen this sample for the following reasons:

1) First year students in the industrial schools are always complaining about the difficulty of ESP course as they used to study general English in the preparatory stage so this study is limited to them.

2) This study is limited to teaching the students the four skills (listening, speaking, reading and writing) as well as the linguistic skills, grammatical structures expressions, abbreviations, terminology, vocabulary and translation.

3) The duration of the study was limited to one academic term.

4) The evaluation tools of this study were limited to pre-posttests of listening, speaking, reading, writing and linguistic skills. 


\subsection{Design of the Experiment}

The study was conducted on first year students, Industrial School, Miet Ghamer Vocational School. The experiment started at the beginning of the first term until the end of June (2018). The study had pre-posttests. An experimental and control groups were exposed to the pre-tests and the post-tests for gathering data. The experimental group was instructed and trained through using the (Task-based Instruction), while the control group received traditional teaching of the same course.

\subsection{The Researcher Had to Select Miet Ghamer Vocational School in Egypt for the Following Reasons}

1) The school is specialized in teaching the industrial subjects.

2) The school has a section of teaching Mechanics.

3) The school is big enough to afford a big number as far as possible.

4) The school accepts males only for (Mechanics Department).

5) The school is the only school in Miet Ghamer City that teaches Mechanics.

6) The researcher contacted the school manager, the deputies and the supervisors of English language department to get an agreement of the experiment and the number of the students as well as selecting a class for the experiment.

7) The sample of the study are (80) students from Miet Ghamer Industrial school. The (80) students are divided into experimental group of (40) students and control group of (40) students of the same age, nearly (15 - 20), the same sex, all are males and majored in Mechanics Department.

\subsection{The Training Program in Its Final form Is Described as the Following}

The program is divided into a teacher's guide and a student's manual.

\subsection{In Constructing This Program Is Was Taken into Consideration the Following Points}

1) Every unit must start with the types of tasks which are used throughout the whole unit.

2) The objectives of these tasks must be presented in both the teacher's guide and the student's manual.

3) The content, the teaching method and the teaching aids are to be mentioned in both the teacher's guide and the student's manual.

4) Evaluation is to be included in the evaluation items following every task and there is a revision task after each unit.

5) Two tests were prepared, one related to the students' communicative skills especially in mechanics. The second test is related to the student's proficiency level through constructing an English proficiency test.

6) Presentation methods including the methods of the task-based instruction 
through conveying the real-world of mechanics inside the classroom.

\subsection{The Researcher Designed the Program through the Following Resources}

1) The researcher followed Orr, (2002) in designing (information gaps and problem solving tasks).

2) The researcher followed Nunan (2002) in the following tasks:

- Real-world tasks

- Communicative activities and language exercises

- Integrating the pedagogical tasks, communicative activities and the language exercises.

3) The researcher adopted from Daroon, (2002) the steps of teaching the experimental group which are the following;

- Making a decision about the unit objectives.

- Making an introduction and a discussion about the topics and the tasks.

- Doing the tasks in small group.

- Helping the students in performing the tasks.

- Revising the learner's input.

- Examining the students' communicative skills and checking their comprehension.

4) The researcher followed Akhbarentaj (2000) in the following points:

- Using the task-based approach in developing the communicative competence.

- Constructing the three task phases: Firstly, the "pre-task" secondly, the "taskcycle" and finally, the "post-task".

- Using two groups through the experience: an experimental group and a control group.

- Moving from fluency to accuracy through using the task-based instruction. 5) The researcher followed Castello, (2003) through the following steps:

- Using task-based instruction to develop the students' language proficiency.

6) The researcher followed Richards and Rodgers (1986) in the task classification according to the following:

- Jigsaw tasks.

- Information gap tasks.

- Problem-solving tasks.

- Decision-making tasks.

- Opinion exchange tasks.

7) The researcher followed Willis (1996) in his classification of the tasks which are:

- Listening tasks.

- Ordering and sorting tasks.

- Problem-solving tasks.

- Creative tasks. 
8) From the previous studies the researcher came up with the following conclusions to be considered during the study.

- Language is considered as a tool for communication.

- The task-based approach can be achieved through communication.

- Real-life situations are the main characteristics of the task-based approach.

- Communication can be achieved through using real-life situations.

- Both ESP syllabus and task based syllabus depend on performing tasks.

- Both ESP syllabus and task based syllabus depend on achieving the learners' needs.

- Both ESP syllabus and task based syllabus can be achieved through achieving real communication.

- The researcher came up with the following definition; that language is a communicative task which can be achieved through using a real life situation of a communicative problem and also the task-based approach can be achieved through a real-life situation of a communicative problem.

- The task-based approach is the best approach which fits the communicative language teaching and communication strategies.

\subsection{Observations Made during the Program}

During the task implementation the researcher noted the following:

1) Students were very interested in developing their English language in their field (mechanics).

2) Students were very excited when they knew that they are going to act real life situations in their filed (mechanics).

3) Students were very interested because they are at the garage with all their tools around them.

4) The English mechanical terms started to be used by students and their language began to develop gradually.

5) Students started using English for various mechanical purposes like diagnosing together the problem in a car and preparing the tools needed to repair it.

6) Students started using English for other various purposes like making an invitation, an apology, an appointment or asking for a permission.

7) The proficiency test and the test of the communicative skills showed improvement in the students' performance and abilities.

8) Students showed a great interest in learning mechanical English through the task-based instruction.

9) Shy students could interact with their classmates as it is a relaxing atmosphere for each one to participate.

10) Students were motivated because they are in real life situations.

11) Task-based instruction gave enough time to the students to use the language creatively.

12) As task-based instruction is a student centered approach, it lays an em- 
phasis on the individual's use of language.

13) Task-based teaching enhances the language proficiency.

The control group did not receive any training of task-based approach. They were taught by using a traditional method of teaching. They only had a pre and post-test in the use of the communicative skills and the English language proficiency. The experimental group also had a pre and a post test in the communicative skills and the English language proficiency. The researcher was the one who taught the program. The units of the book were divided into three tasks dealing with different topics.

\section{Results and Conclusions of the Study}

\subsection{Testing Hypothesis 1}

The researcher hypothesized that there will be significant difference between the mean scores of the experimental group in the pre and posttest favoring the post test. Analysis of data revealed a significant difference between the mean scores of the experimental group in the pre and post applications in the English language proficiency test favoring the post application. Analysis of data using-test showed that the obtained $(t)$ value (20.98) is significant at .01 level. Thus the first hypothesis is accepted. Table 1 presents a summary of the data analysis.

\subsection{Statistical Analysis of the Experimental Group in the Pre and Post Application of English Language Proficiency Test}

1) Frequencies (Table 2)

2) Frequency Table

The pre-test values (Table 3) show the real marks of the students before the experiment and prior applying the task-based approach.

The pre-test values (Table 4) show the real marks of the students after the experiment in which the task based approach has been utilized. The marks were significant and showed progress in their language acquisition.

\subsection{Testing Hypothesis 2}

Hypothesis 2 predicted significant differences between the mean scores of the experimental group in the pre and post applications of the English language communicative skills test favoring the post application. Analysis of the data revealed a significant difference between the mean scores of the experimental group in the pre and post applications of the English language communicative skills test favoring the post application. Analysis of the data using T-test showed that the obtained " $t$ " value (16.03) is significant at .01 level. Thus the second hypothesis approved to be true. The following table presents a summary of the data analysis.

Table 5 represents the scores of 40 students before the experiment.

Table 6 represents the students' score after the experiment. 
Table 1. T-test analysis of the experimental group in the pre and post application of English language proficiency test.

\begin{tabular}{cccccc}
\hline Application & Subjects & Mean & Standard deviation & Standard error of mean & "T" value \\
\hline Pre-testing & 40 & 47.750 & 2.50 & .39 & 20.98 \\
Post-testing & 40 & 58.025 & 2.27 & .35 & \\
\hline
\end{tabular}

"T" value is significant at .01 level.

Table 2. Statistics.

\begin{tabular}{|c|c|c|c|}
\hline & & Pre-Test & Post-Test \\
\hline \multirow{2}{*}{$\mathrm{N}$} & Valid & 40 & 40 \\
\hline & Missing & 0 & 0 \\
\hline \multicolumn{2}{|r|}{ Mode } & $46.00^{\mathrm{a}}$ & 60.00 \\
\hline \multicolumn{2}{|r|}{ Range } & 13.00 & 9.00 \\
\hline \multicolumn{2}{|r|}{ Minimum } & 43.00 & 53.00 \\
\hline \multicolumn{2}{|r|}{ Maximum } & 56.00 & 62.00 \\
\hline
\end{tabular}

Multiple modes exist. The smallest value is showed.

Table 3. Pre-test values.

\begin{tabular}{cccccc}
\hline & Frequency & Percent & Valid Percent & Cumulative Percent \\
\hline 43.00 & 1 & 2.5 & 2.5 & 2.5 \\
45.00 & 6 & 15.0 & 15.0 & 17.5 \\
& 46.00 & 9 & 22.5 & 22.5 & 40.0 \\
& 47.00 & 4 & 10.0 & 10.0 & 50.0 \\
Valid & 58.00 & 5 & 12.5 & 12.5 & 62.5 \\
& 49.00 & 4 & 10.0 & 10.0 & 72.5 \\
& 50.00 & 9 & 22.5 & 22.5 & 95.0 \\
& 53.00 & 1 & 2.5 & 2.5 & 97.5 \\
56.00 & 1 & 2.5 & 2.5 & 100.0 \\
\hline
\end{tabular}

Table 4. Post-test values.

\begin{tabular}{cccccc}
\hline & Frequency & Percent & Valid Percent & Cumulative Percent \\
\hline 53.00 & 2 & 5.0 & 5.0 & 5.0 \\
& 54.00 & 3 & 7.5 & 7.5 & 12.5 \\
& 55.00 & 2 & 5.0 & 5.0 & 17.5 \\
& 56.00 & 2 & 5.0 & 5.0 & 22.5 \\
Valid & 4 & 10.0 & 10.0 & 32.5 \\
& 58.00 & 5 & 12.5 & 12.5 & 45.0 \\
& 59.00 & 9 & 22.5 & 22.5 & 67.5 \\
& 50.00 & 12 & 30.0 & 30.0 & 97.5 \\
& 1 & 2.5 & 2.5 & 100.0 \\
\hline
\end{tabular}


Table 5. Pre-test statistical analysis.

\begin{tabular}{|c|c|c|c|c|c|}
\hline & & Frequency & Percent & Valid Percent & Cumulative Percent \\
\hline \multirow{16}{*}{ Valid } & 41.00 & 2 & 5.0 & 5.0 & 5.0 \\
\hline & 42.00 & 2 & 5.0 & 5.0 & 10.0 \\
\hline & 43.00 & 3 & 7.5 & 7.5 & 17.5 \\
\hline & 45.00 & 2 & 5.0 & 5.0 & 22.5 \\
\hline & 46.00 & 3 & 7.5 & 7.5 & 30.0 \\
\hline & 47.00 & 2 & 5.0 & 5.0 & 35.0 \\
\hline & 48.00 & 3 & 7.5 & 7.5 & 42.5 \\
\hline & 49.00 & 3 & 7.5 & 7.5 & 50.0 \\
\hline & 50.00 & 4 & 10.0 & 10.0 & 60.0 \\
\hline & 51.00 & 6 & 15.0 & 15.0 & 75.0 \\
\hline & 53.00 & 2 & 5.0 & 5.0 & 80.0 \\
\hline & 54.00 & 2 & 5.0 & 5.0 & 85.0 \\
\hline & 55.00 & 4 & 10.0 & 10.0 & 95.0 \\
\hline & 56.00 & 1 & 2.5 & 2.5 & 97.5 \\
\hline & 57.00 & 1 & 2.5 & 2.5 & 100.0 \\
\hline & Total & 40 & 100.0 & 100.0 & \\
\hline
\end{tabular}

Table 6. Post-test statistical analysis.

\begin{tabular}{cccccc}
\hline & Frequency & Percent & Valid Percent & Cumulative Percent \\
\hline 50.00 & 1 & 2.5 & 2.5 & 2.5 \\
51.00 & 1 & 2.5 & 2.5 & 5.0 \\
53.00 & 1 & 2.5 & 2.5 & 7.5 \\
& 54.00 & 3 & 7.5 & 7.5 & 15.0 \\
& 55.00 & 2 & 5.0 & 5.0 & 20.0 \\
Valid & 56.00 & 6 & 15.0 & 15.0 & 35.0 \\
& 57.00 & 6 & 15.0 & 15.0 & 50.0 \\
& 58.00 & 6 & 15.0 & 15.0 & 65.0 \\
59.00 & 8 & 20.0 & 20.0 & 85.0 \\
60.00 & 6 & 15.0 & 15.0 & 100.0 \\
& & 6 & 100.0 & 100.0 &
\end{tabular}

The following chart is to compare between The English Language Communicative Skills Post-Test and the Pre Test of the experimental Group (Figure 1).

The following chart is to compare between Language proficiency Post-Test and Pre-Test of the Control Group (Figure 2).

The following chart is to compare between communicative language skills Pre-Test and Post-Test of the experimental group (Figure 3). 
The following chart is to compare between English language proficiency test pre and posttests of the experimental group (Figure 4).

General Comparative chart of the experimental group between all pre and posttests (Figure 5).

The statistical analysis shows the difference in the students' scores favoring the all the Post-Tests of the experimental group due to the application of the Task-Based Approach.

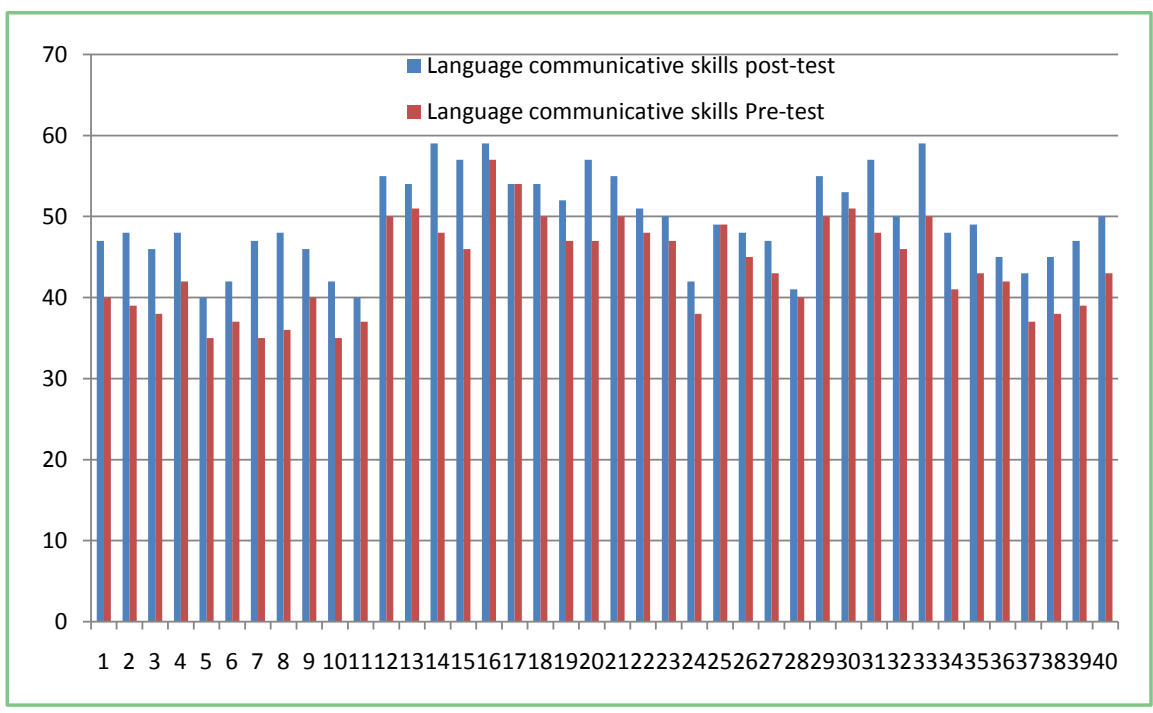

Figure 1. Shows a remarkable progress in the students' scores of the Post-Test (Language communicative skills) than that of the Pre-Test, favoring the post test of the experimental group.

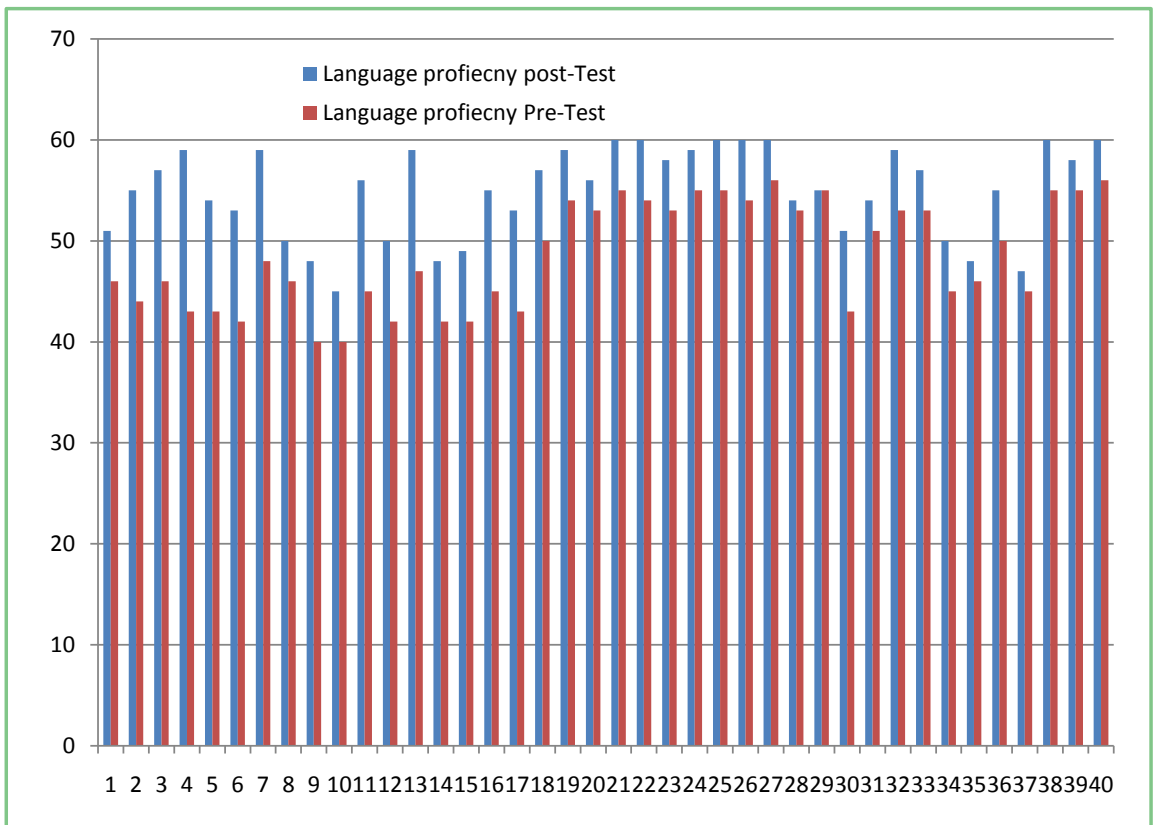

Figure 2. Indicate the little difference between the Pre-Test and the Post-Test of English language proficiency of the control group due to the traditional method of teaching that they have been receiving. 


\subsection{Testing Hypothesis 3}

Hypothesis 3 predicted significant differences between the mean scores of the experimental and control groups in the post applications of the English language communicative skills test favoring the experimental group. Analysis of the data revealed a significant difference between the two groups favoring the experimental group. Analysis of the data using T-test showed that the obtained " $\mathrm{t}$ " value (8.12) is significant at .01 level. Thus the third hypothesis proved to be true. A summary of the analysis of the data is presented in Table 7.

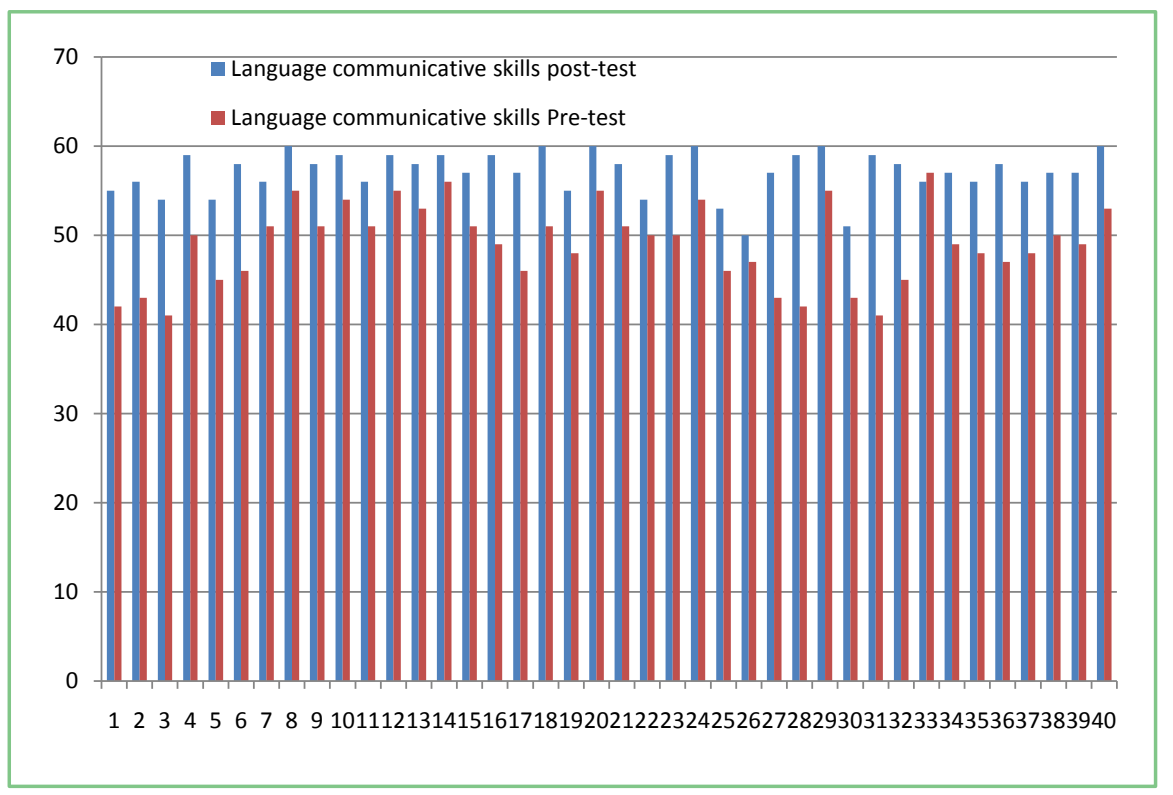

Figure 3. Indicates a remarkable progress between the Pre-Test and the Post-Test favoring the Post-Test of the experimental group due to the application of the task-based approach.

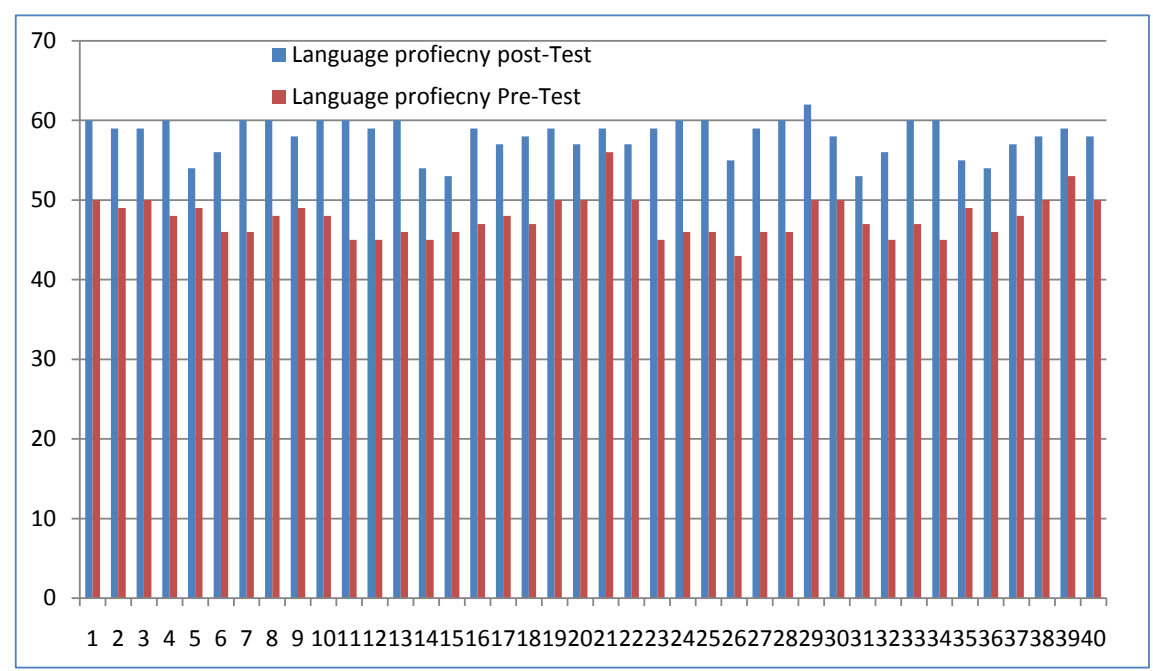

Figure 4. Indicates a remarkable progress between the Pre-Test and the Post-Test favoring the Post-Test of the experimental group due to the application of the task-based approach. 


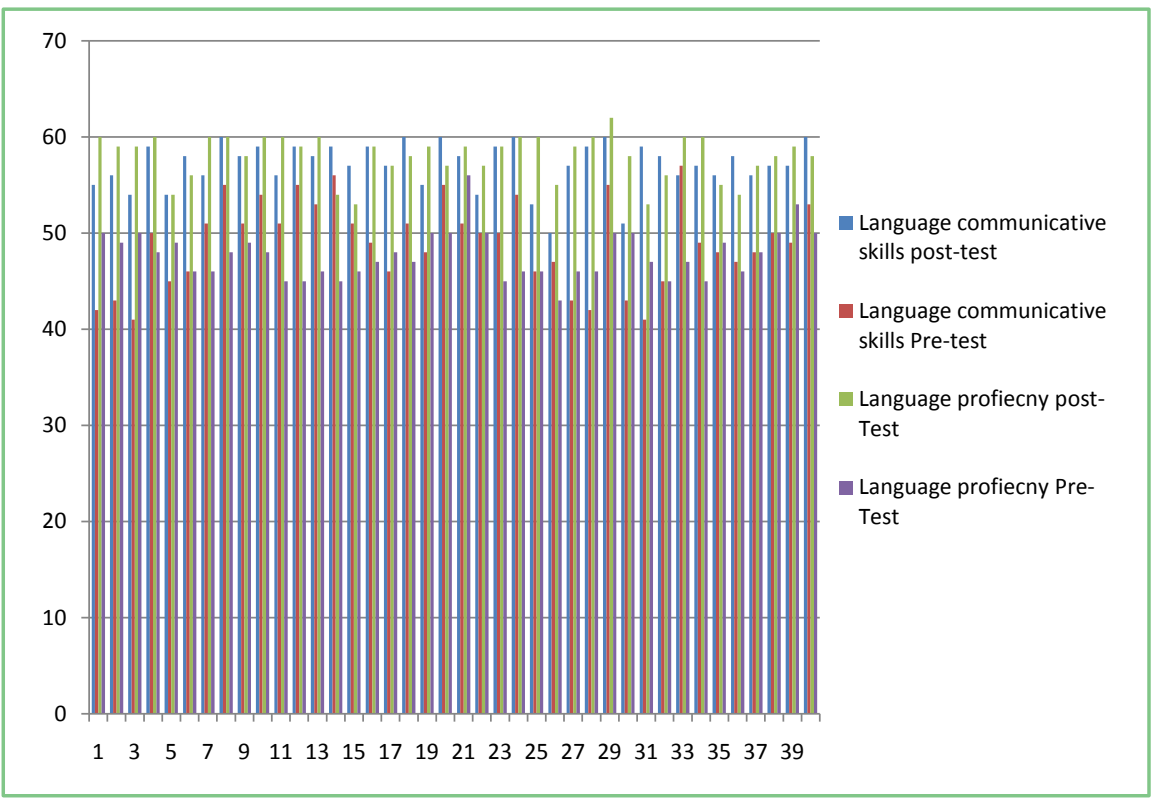

Figure 5. Is a comprehensive comparison of the four tests: 1) Language communicative skills Pre-Test. 2) Language communicative skills Post-Test. 3) Language proficiency Pre-Test. 4) Language proficiency Post-Test.

Table 7. T-test of the two groups in the post application of English language communicative skills test.

\begin{tabular}{cccccc}
\hline Group & Subjects & Mean & Standard deviation & Standard error of mean "T" value \\
\hline Experimental & 40 & 49.47 & 5.49 & .86 & 8.12 \\
Control & 40 & 57.10 & 2.44 & .38 & \\
\hline
\end{tabular}

"T" value is significant at .01 level.

\subsection{Statistical Analysis of the Two Groups in the Post Application of English Language Communicative Skills Test}

Compare between the two groups the experimental and the control in the post test of English language communicative skills test.

\subsection{Testing Hypothesis 4}

Hypothesis 4 predicted significant differences between the mean scores of the experimental and controlled groups in the post application of the English language proficiency test favoring the experimental group. Analysis of the data (Tables 8-10) revealed a significant difference between the two groups favoring the experimental group. Analysis of the data using t-test showed that the obtained " $t$ " value (10.30) is significant at .01 level. Thus the fourth hypothesis proved to be true. A summary of the analysis of data is presented in Table 11.

\subsection{Statistical Analysis of the Two Groups in the Post Application of English Language Proficiency Test (Table 12)}

The pervious findings (Figures 1-5) answer the question of the research and in- 
dicate that the suggested program has a positive large effect in enhancing EFL proficiency and the communicative skills of the first year students, The Industrial High School, Miet Ghamer City, Mansoura. Egypt.

Table 8. Statistics.

\begin{tabular}{cccc}
\hline & & Post-test Control Group & Post-Test Experimental Group \\
\hline $\mathrm{N}$ & Valid & 40 & 40 \\
& Missing & 0 & 0 \\
& Mode & 48.00 & 59.00 \\
& Range & 19.00 & 10.00 \\
& Minimum & 40.00 & 50.00 \\
Maximum & 59.00 & 60.00 \\
\hline
\end{tabular}

Table 9. One-Sample statistics.

\begin{tabular}{ccccc}
\hline & $\mathrm{N}$ & Mean & Std. Deviation & Std. Error Mean \\
\hline Post-test control Group & 40 & 49.4750 & 5.49586 & .86897 \\
Post-test experimental Group & 40 & 57.1000 & 2.44740 & .38697 \\
\hline
\end{tabular}

Table 10. One-Sample test.

\begin{tabular}{ccccccc}
\hline & \multicolumn{6}{c}{ Test Value $=0$} \\
\cline { 2 - 5 } & $\mathrm{T}$ & Df & Sig. (2-tailed) & $\begin{array}{c}\text { Mean } \\
\text { Difference }\end{array}$ & $\begin{array}{c}\text { 95\% Confidence Interval } \\
\text { of the Difference }\end{array}$ \\
\cline { 5 - 7 } & & & & & Lower & Upper \\
\hline $\begin{array}{c}\text { Post-test Control } \\
\text { Group }\end{array}$ & 56.935 & 39 & .000 & 49.47500 & 47.7173 & 51.2327 \\
$\begin{array}{c}\text { Post-test } \\
\text { experimental Group }\end{array}$ & 147.558 & 39 & .000 & 57.10000 & 56.3173 & 57.8827 \\
\hline
\end{tabular}

Table 11. T-test analysis of the two groups in the post application of English language proficiency test.

\begin{tabular}{cccccc}
\hline Group & Subjects & Mean & Standard deviation & Standard error of mean & "T" value \\
\hline Experimental & 40 & 54 & 4.43 & .70 & 10.30 \\
Control & 40 & 58 & 2.27 & .35 & \\
\hline
\end{tabular}

"T" value is significant at .01 level.

Table 12. Statistics.

\begin{tabular}{|c|c|c|c|}
\hline & & control & Exp \\
\hline \multirow{2}{*}{$\mathrm{N}$} & Valid & 40 & 40 \\
\hline & Missing & 0 & 0 \\
\hline \multicolumn{2}{|r|}{ Mode } & 60.00 & 60.00 \\
\hline \multicolumn{2}{|r|}{ Range } & 15.00 & 9.00 \\
\hline \multicolumn{2}{|r|}{ Minimum } & 45.00 & 53.00 \\
\hline \multicolumn{2}{|r|}{ Maximum } & 60.00 & 62.00 \\
\hline
\end{tabular}




\section{Summary of the Findings}

\subsection{The Results of the Study Can Be Summarized in the Following Points}

1) There are statistically significant differences between the mean scores of the experimental group in the pre-post applications of the English language proficiency test favoring the post application.

2) There are statistically significant differences between the mean scores of the experimental group in the pre-post applications of the communicative skills test favoring the post application.

3) There are statistically significant differences between the mean scores of the experimental group and control group in the post application of communicative skills test favoring the experimental group.

4) There are statistically significant differences between the mean scores of the experimental group and control group in the post application of English language proficiency test favoring the experimental group.

5) There is a positive correlation between the communicative skills and EFL proficiency.

\subsection{Discussion of the Findings}

In this research, the researcher intended to investigate the effectiveness of using task-based instruction in enhancing students, EFL proficiency and communicative skills. The findings of the research indicated that the suggested program (Task-based instruction) resulted in a remarkable progress and enhancement in the first year, Industrial students EFL proficiency and communicative skills. So the result of the present study can be stated as the following:

The first result: "There are statistically significant differences between the mean scores of the experimental group in the pre and post applications of the English language proficiency test favoring the post application" And that was proved by many other studies investigated the effectiveness of using task-based approach in the enhancement of industrial students EFL proficiency and communicative skills. Oxford, (1996) sated that the conscious proficiency and the successful learners employ a wider variety of strategies to improve their language skills and performance. Many other studies confirm the correlation between any strategy use task-based instruction and the level of students' proficiency. Wharton's (1997) study of 678 bilingual university students studying Japanese and French course in Singapore showed significant correlation between strategy use and French/Japanese proficiency, with more successful learners employ more frequently the learning strategies than do poor proficiency learners.

The second result of the present study indicated that "There are significant differences between the mean score of the experimental group in the pre and post application of the communicative skills test favoring the post applications of the experimental group". The second result is in harmony with the findings of Flew and Harrison (2003), they reported that training in an effective task-based 
approach showed significant differences in the pre-posttest of the experimental group students favoring the post application of the communicative skills test.

The third result of this study can be stated in the following "there are statistically significant differences between the mean scores and of the experimental and control groups in the post application of the communicative skills test favoring the experimental group". Akbarentaj (2000), confirmed the same result. He conducted his experiments through using two groups, an experimental group and a control group in order to measure the effectiveness of the task-based approach in enhancing communicative skills. The result revealed that the experimental group outperformed the control group with a statistically significant difference of the mean scores, then the task-based language teaching can be considered as an effective teaching in which we can enhance the students' communicative skills.

The fourth result of the present study can be indicated in the following "there are statistically significant differences between the mean scores of the experimental and the control group in the post application of the English language proficiency test favoring the experimental group". Abd-Latif Ahmed (2006) indicated that there are significant differences (favoring the experimental group) between the mean scores obtained by the subjects of the experimental group and the control group on the post test of English language proficiency. The experimental group surpassed the control group in the post-performance of the language proficiency test. The significant difference showed that training in the effective communication strategies was very effective in improving the students' language proficiency.

The fifth result of the present study indicated that there is a positive correlation between the communicative skills and the EFL proficiency skills. This result confirms many previous studied. Canal and Swain (1980). Which describes the communicative competence as the learner's ability to use the language in listening, speaking, reading and writing in the linguistic, sociolinguistic and discourse competence.

\subsection{Conclusion}

We need to involve students in thinking dependently the whole process of the language learning. The teaching activity should create opportunities for students to try out different skills and interaction and negotiation through group work. By encouraging students to learn from other classmates and authentic tasks, we are helping them to consider for themselves what leads to their success and failure in language using. They should make better decisions about how to improve their language using practice. Hence, the teacher is not only source of information any more, but acts as facilitator so that students can actively interpret and organize the information they are given, fitting it into prior knowledge. The teachers should seek new ways to create an effective environment for language learners to learn.

The procedures of this study revealed the effectiveness of Using Task-based 
Instruction in Enhancing Vocational students EFL proficiency and Communicative Skills. Thus, this study can be concluded in the following points:

1) Task-based instruction helped in improving the students' EFL proficiency and communicative skills.

2) Task-based instruction provided a relaxing teaching-learning environment.

3) Task-based instruction helped the learner to be a positive participant not a negative recipient during the teaching-learning process.

4) Task-based instruction helped the students to be more active, initiative and creative most of the time through practicing the language in during implementing tasks.

5) Task-based instruction provides realistic learning and it puts students into real life situations.

6) Task-based instruction provides an opportunity of using the four skills: listening, speaking, reading and writing, the thing that helps students to speak fluently.

7) Task-based instruction helps students to listen and respond to different types of spoken language and produce a variety of types of writing.

8) Task-based instruction gives opportunities and finds strategies for getting practice in using the language inside and outside the classroom.

9) Task-based instruction encourages different activities such as (situations, dialogues, improvisation, role-playing, problem-solving, interviews, debates, games and the like...).

10) Task-based instruction motivates students to learn a wide range of conventional and idiomatic expressions for their conversation.

11) Task-based instruction encourages the use of teaching media especially audio-visual aids, the thing that makes the students enthusiastic and eager to learn.

\subsection{Recommendations of the Study}

In the light of the results and conclusions of the present study, the following recommendations are suggested:

1) Students enrolled in the first year, industrial schools should be trained in an effective task-based instruction through a pre-service program.

2) EFL teachers in industrial schools should receive a training program on how to use the task-based approach to improve the students' language proficiency and communicative skills.

3) Curriculum designer should depend on the task-based approach in their curriculum designing as it helps the learners to acquire the language properly.

4) In order to apply the task-based approach inside the classroom, many material and teaching aids should be prepared in advance.

5) EFL teachers should provide students with opportunities to use the language in real life situations.

6) During instructing students, EFL teachers should provide students with a relaxing and interactive learning environment. 
7) Industrial schools as well as general school should apply the task-based approach in teaching English as a second language as it improves the students' fluency.

\subsection{Suggestions for Further Research}

1) Designing a program of task-based instruction for developing the students' proficiency and communicative skills in the university stages.

2) Studying the effect of using task-based instruction in developing the students' reading and writing skills.

3) Developing a program of task-based instruction at different faculties.

4) Extended researches are needed to examine the relationship between the task-based instruction and language proficiency.

\section{Conflicts of Interest}

The authors declare no conflicts of interest regarding the publication of this paper.

\section{References}

Anthony, L. (1997). English for Specific Purposes: What Does It Mean? Why Is It Different? http://www.antlab.sci.waseda.ac.jp/abstracts/esparticle.html

Dudley-Evans, T. (1984). The Use of an ESP Textbook in Egyptian Secondary Schools. English for Specific Purposes in the Arab World. Papers from the Summer Institute on ESP in the Arab World Held at the University of Aston in Birmingham. A Language Studies Unit Publication.

Johns, A., \& Dudley Evans, T. (1991). English for Specific Purposes: International in Scope, Specific in Purpose. TESOL Quarterly, 25, 297-314. https://doi.org/10.2307/3587465

Lixin, X. (2004). Vocabulary Learning Strategies in an ESP Context.

Long, M. H. (1985). A Role for Instruction in Second Language Acquisition: Task-Based Language Teaching.

Long, M., \& Crookes, G. (1993). Units of Analysis in Syllabus Design.

Nunan, D. (1989) Designing Tasks for a Communicative Room (p. 56). Cambridge: Cambridge University Press.

Nunan, D. (2002). Task-Based Language Teaching. Cambridge Language Teaching Library.

Nunan, D. (2004). Task-Based Language Teaching. Cambridge: Cambridge University Press.

Oxford, R. (2001). Integrated Skills in The ESL/EFL Classroom. ERIC Digest. ED 456670. Washington DC: ERIC Clearinghouse on Languages and Linguistics.

Prabhu, N. S. (1987). Second Language Pedagogy. Oxford: Oxford University Press.

Robinson, P. (1991). The Role of Needs Analysis in Adult ESL Program Design. In ESP Today: A Practitioner's Guide. Hertfordshire, UK: Prentice Hall.

Smoak, R. (2003). What Is English For Specific Purposes? English Teaching Forum, 8, 22-27.

Widdowson, H. (1987). English for Academic and Technical Purposes: Criteria for Course 
Design. Methodology in TESOL: A Book of Readings. Rowley, New York: Newbury House Publishers.

Willis, J. A. (1996). Framework for Task-Based Learning. London: Longman. 